DOI https://doi.org/10.32782/2305-9389/2020.23.23

УДК 614.2

Криничко Лілія,

кандидат медичних наук, здобувач кафедри економічної безпеки, публічного управління та адміністрування Держсавного університету «Житомирська політехніка»

Савіцький Владислав, аспірант кафедри обліку і аудиту Державного університету «Житомирська політехніка»

Ватанов Андрій, здобувач кафедри економічної безпеки, публічного управління та адміністрування Державного університету «Житомирська політехніка»

Цепенда Володимир, здобувач кафедри обліку і аудиту Державного університету «Житомирська політехніка»

\title{
ІСТОРИЧНІ АСПЕКТИ ДЕРЖАВНОГО РЕГУЛЮВАННЯ АУДИТУ ЯК ВИКОНАННЯ КОНТРОЛЬНОЇ ФУНКЦІї ДЕРЖАВИ
}

\begin{abstract}
У статті проаналізоване теоретичне підгрунтя наукових досліджень за економічними спеціальностями. Уточнено питання еволючії розвитку аудиту як професійної та господарської діяльності, щуо актуалізується сьогодні з позичії ідентифікаиії його властивостей, щчо проявлялися на відповідному етапі розвитку суспільства. Проведено аналіз сучасного етапу розвитку аудиторської діяльності у світі, щзо вказує на відсутність єдиних світових підходів до регулювання аудиту. Кожна країна розробляє власні підходи до інструкиійного забезпечення регулювання аудиту та встановлює специфічні вимоги до діяльності аудиторської фірми. Зауважено, щьо основною характеристикою сучасного аудиту є встановлення вимог власне до кадрового потенціалу аудиторської фірми. Виділено три основоположні етапи розвитку аудиту в контексті його теорій та завдань. Доведено, щзо економічні відносини, щзо характеризують той чи інший період суспільного розвитку, визначали основну мету аудиту й відповідні методологічні положення. Виокремлено щзо витоки аудиту як виду фінансового контролю сягають стародавніх часів. Перші прояви контрольної діяльності можна прослідкувати в країнах стародавнього світу - Індії, Сгипті, Вавилоні, Китаї. Уточнено, щуо історія аудиту як економічного явища сягає корінням у глибину століть. Елементи контролю застосовувалися в Стародавньому Вавилоні, де приблизно 5000 років тому використовувалися глиняні дощечки, які являли собою підтверджені аудитором звіти. Охарактеризовано, щзо сучасний стан аудиту як виду незалежного фінансового контролю та як виду господарської діяльності в різних краӥнах світу характеризується певним станом соціально-економічних відносин. Вивчаючи сучасний стан розвитку аудиту та діяльності аудиторських фірм у країнах світу, насамперед варто наголосити на тенденції до уніфікації прочесу регулювання аудиту та аудиторської діяльності.
\end{abstract}

Ключові слова: аудит, державне регулювання, контроль, функиї держави, історія аудиту.

Krynychko Liliia, Savitskyi Vladyslav, Vatanov Andrii, Tsependa Volodymyr. Historical aspects of the government regulation of audit as an execution of the control function of the state

The statistic has analyzed the theoretical understanding of scientific knowledge for economic specialties. It has been clarified the nutrition of the evolution of the audit as a professional and state-run performance, as well as to be updated from the position of the identification of the authorities, which were manifested in the general stage of development of the suspension. An analysis of the day-to-day stage of the development of audit performance in the light was carried out, so that it was ordered on the day-to-day of one person's decisions before the audit was regulated. The skin of the country is going to develop the state of affairs before the instructive safety of the regulation of the audit will be established and the specific measures will be established until the validity of the audit firm. It is respected that the main characteristic of the current audit is the establishment of the audit firm to the personnel potential. We saw three fundamental stages of development of audit in the context of theories and theories. It has been reported that the economic development, which characterizes the same period of suspension development, has begun the main audit meta and the methodological provisions have begun. The auditor's rounds are overwhelming as the type of financial control is taking place in ancient hours. The first to show control power can be seen in the lands of the ancient world of India, Egypt, Babylon, China. It has been clarified that the history of the audit as an economic phenomenon is found in the future. The elements of control were stashed in Old Babylon, about 5,000 years ago, clay tablets were installed, which represented the auditor's approval

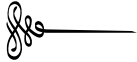


of the sound. It is characterized that the current audit camp is characterized by a singing camp of socially-economically in the form of state-owned activity in the rural lands. Studying the current state of development of auditing and the activities of audit firms in the world, first of all it is worth emphasizing the tendency to unify the process of regulating auditing and auditing.

Key words: audit, state regulation, control, state functions, audit history.

Актуальність дослідження. Теоретичним підгрунтям наукових досліджень за економічними спеціальностями (зокрема, «Бухгалтерський облік», «Економічний аналіз», «Аудит») $\epsilon$ вивчення історичних аспектів за об'єктом дослідження. Застосування історичного підходу до наукових досліджень визначає особливості еволюціє об'єкта в різних соціально-економічних умовах. Розвиток аудиту як виду практичної діяльності, удосконалення його методики приводили до зміни концепцій і формування його основних положень, які набувають форми концептуальних основ і втілюються в конкретних теоріях аудиту (поліцейській теорії, теорії контролінгу, теорії консалтингу). Виникнення цих теорій пов'язане не тільки $з$ кризовими явищами в економіці, але і $з$ нагальною потребою вдосконалення технології аудиту, використанням якісно нових концепцій [10].

Питання еволюції розвитку аудиту як професійної та господарської діяльності актуалізується нині 3 позиції ідентифікації його властивостей, що проявлялися на відповідному етапі розвитку суспільства. Адже аудит як вид бізнесу виконує сукупність суспільно-економічних функцій, що полягають у формуванні довіри суб'єктів господарської діяльності, які оприлюднюють фінансову звітність. Вивчення історичних положень аудиту в Україні та світі дасть змогу виявити причини становлення аудиту як особливого інституту ринкової економіки. На думку Л.В. Гуцаленко, аудит набув окремого інституту ринкової економіки, до якого ставляться вимоги державного та міжнародного рівня та який має певні зобов'язання перед суспільством [9, с. 349]. Отже, застосування історичного підходу дасть змогу виявити, яким чином змінюється аудиторська діяльність у різних соціально-економічних умовах, що є основою врахування факторів внутрішнього середовища в економічному аналізі діяльності аудиторських фірм.

Аналіз останніх досліджень. Питання становлення та розвитку аудиту на різних етапах соціально-економічних трансформацій порушували Л.В. Гуцаленко, 3.О. Душко, О.А. Петрик, І.І. Пилипенко, Г.М. Давидов, Т. Каменська, В. Максімова, А.Н. Кизилов, И.Н. Богатая, Ф.Л. Дефлиз, Г.Р. Дженик, О. Рейли, М.Б. Хирш, М.А. Азарська, С.М. Бичкова, А.В. Газарян, Г.И. Козлова, М.Ю. Медведев, Т.Г. Шешукова, Д. Декер, П.П. Баранов, А.А. Шапошников, В.П. Бондар, Н.М. Проскуріна та інші. Автори розглядали історичні аспекти в контексті трансформації методологічних положень та розвитку інституційного забезпечення. 3 позицій вивчення господарської діяльності аудиторських фірм як об'єкта економічного аналізу ці аспекти є важливими, адже визначають рівень економічного потенціалу, якому має відповідати суб'єкт аудиторської діяльності на кожному етапі соціально-економічних відносин.

Виклад основного матеріалу. Зарубіжна дослідниця проблем аудиту О.С. Лавренова вказує: «Незважаючи на те, що цілі і концепції аудиту, якими керуються сучасні аудитори, були практично невідомі на початку $\mathrm{XX}$ століття, аудит того чи іншого типу виконувався протягом історичного ведення документів комерційних і державних фінансів. Спочатку термін «аудитор» означав «той, хто чує», і це відповідало епосі, коли урядові фінансові звіти затверджувалися тільки після публічних читань, на яких звітність зачитувалася вголос. Із середньовічних часів і до початку промислової революції аудитори працюють і формують звітність добросовісно на посадах в уряді або комерції відповідно до службових обов'язків» [13, с. 35$]$.

Я.В. Соколов та С.М. Бичкова наголошують, що в сторичному контексті аудит пройшов багато етапів, що визначає різноманітність теорій його дослідження. Зокрема, автори зазначають, що «кардинальні зміни в аудиторську діяльність, формування нових теорій, поява нових підходів до проведення аудиту і концепцій тісно пов'язані з фінансовими скандалами або економічними кризами, які висвітлюють основні недоліки аудиту і вимагають його подальшого вдосконалення. Нині виділяють три основні теорії аудиту: теорію адекватності, теорію контролінгу і теорію консалтингу» [19].

Історичні аспекти розвитку аудиту досліджувалися багатьма вченими проте єдиного підходу щодо його періодизації не існує. Це пов'язано із сукупністю об'єктивних причин:

- по-перше, теорія, що лежить в основі дослідження. У процесі вивчення аудиту більшість дослідників беруть за основу свого дослідження певну теорію, яка може бути пов'язана 3 теорією розвитку науки (наукових досліджень) загалом (наприклад, нормативізм або позитивізм, інституціоналізм або неоінституціоналізм), економічною теорією (наприклад, теорія зацікавлених сторін, біхевіоризм, класична економічна та неокласична економічна наука та інші), теорією суспільного розвитку (індустріальна економіка, постіндустріальна економіка, інформаційна (цифрова) економіка, економіка сталого розвитку суспільства та інші), теорією власне аудиту (поліцейська теорія, теорія контролінгу, теорія консалтингу); 
- по-друге, об’єкт дослідження. Залежно від об’єкта дослідження визначається специфіка застосування історичного підходу. Так, об'єктом дослідження може виступати методологія аудиту, а отже, дослідник буде вивчати особливості методів аудиту на різних історичних етапах, що визначатиме етапи розвитку аудиту. За умови, що аудит досліджується з позиції господарської діяльності, вивчення історичних аспектів буде відбуватися в контексті розвитку консалтингу як сфери бізнесу на різних етапах соціально-економічних відносин. У процесі вивчення системи регулювання аудиту є потреба в дослідженні еволюції інститутів регулювання як аудиту, так і всієї господарської діяльності.

- по-третє, методи та завдання дослідження. Залежно від поставлених завдань до наукового дослідження буде визначатися порядок застосування сторичного підходу. Зокрема, дослідник може пропонувати періодизацію розвитку аудиту за властивостями його об'єкта, суб'єкта чи порядку реалізації функцій аудиту.

Нами вивчені певні підходи до періодизації розвитку аудиту. А.Н. Кизилов, І.Н. Богатая пропонують власну періодизацію аудиту в контексті основних його теорій (табл. 1).

Таблиця 1

Етапи розвитку аудиту в контексті його теорій за А.М. Кизиловим та І.М. Богатою [10]

\begin{tabular}{|c|c|c|c|}
\hline Етап & Назва & Період & Теорія \\
\hline \multirow{2}{*}{ Перший етап } & Підтверджуючий аудит & $\begin{array}{c}1862- \\
\text { перша чверть ХХ ст. }\end{array}$ & $\begin{array}{c}\text { Поліцейська теорія, } \\
\text { або теорія «сторожового пса» }\end{array}$ \\
\hline \multirow{2}{*}{ Другий етап } & $\begin{array}{c}\text { Системно орієнтований } \\
\text { аудит }\end{array}$ & $\begin{array}{c}\text { перша чверть ХХ ст. }- \\
1983 \mathrm{p} .\end{array}$ & $\begin{array}{c}\text { Теорії контролінгу, } \\
\text { або теорії «собаки-шукача» }\end{array}$ \\
\hline \multirow{2}{*}{ Третій етап } & Консалтинговий & $\begin{array}{c}\text { Теорія консалтингу, } \\
\text { по теперішній час }\end{array}$ & або теорія «собаки-поводиря» \\
\hline
\end{tabular}

Так, автори виділили три основоположні етапи розвитку аудиту в контексті його теорій та завдань. Такі теорії аудиту, як поліцейська, контролінгу та консалтингу, відповідають певному періоду соціально-економічних відносин. Економічні відносини, що характеризують той чи інший період суспільного розвитку, визначали основну мету аудиту й відповідно до цього визначали методологічні положення.

К.Т. Султанова виділяє такі етапи аудиту: «1) до 1500 р.; 2) 1500-1830 (1860) р.; 3 ) 1830 (1860) 1905 р.; 4) 1905-1933 рр.; 5) 1933-1940 рр.; 6) з 1940 року по теперішній час» [21]. Проте характеристику зазначених етапів вона не надає.

Н.Г. Усанова пропонує розглядати еволюцію аудиту за п’ятьма етапами в контексті різних соціальноекономічних відносин, що представлено в табл. 2.

Таблиця 2

Етапи розвитку аудиту в контексті його завдань та механізму їх реалізації [23]

\begin{tabular}{|c|c|c|}
\hline Етап & Назва & Характеристика \\
\hline $\begin{array}{c}\text { Перший } \\
\text { етап }\end{array}$ & $\begin{array}{c}\text { Поява } \\
\text { перевірки }\end{array}$ & $\begin{array}{l}\text { Ще приблизно } 4000 \text { років до н.е. давні цивілізації Близького Сходу активно ство- } \\
\text { рювали держави і налагоджували господарську діяльність. Щоб враховувати свої } \\
\text { доходи і витрати, вони мали складати звіти. Це призвело до необхідності органі- } \\
\text { зації перевірки звітності, основна мета яких полягала у зменшенні помилок і зло- } \\
\text { вживань із боку чиновників. В Афінах у V ст. до н.е. усі доходи і витрати держави } \\
\text { контролювала фінансова система народних зборів, куди входили аудитори. } \\
\text { У Римській республіці державні фінанси контролював Сенат, а аудитори під } \\
\text { наглядом скарбника перевіряли державний бюджет. У римлян була розроблена } \\
\text { складна система перевірок і взаємоперевірок посадових осіб, які несли відпові- } \\
\text { дальність за збір податків }\end{array}$ \\
\hline $\begin{array}{c}\text { Другий } \\
\text { етап }\end{array}$ & $\begin{array}{c}\text { Розвиток } \\
\text { перевірки }\end{array}$ & $\begin{array}{l}\text { Цей етап еволюції перевірки тривав із } 1500 \text { по } 1830 \text { (1860) рр. У цей час цілі і } \\
\text { прийоми такого контролю не були змінені і складалися з виявлення помилок і } \\
\text { перевірки чесності осіб, відповідальних за податкові платежі. Також у цей час } \\
\text { істотно підвищилося значення незалежної перевірки фінансової звітності, бо від- } \\
\text { бувся поділ між власниками підприємства на керуючих і інвесторів }\end{array}$ \\
\hline $\begin{array}{c}\text { Третій } \\
\text { етап }\end{array}$ & $\begin{array}{l}\text { Виникнення } \\
\text { аудиту } \\
\text { в сучасному } \\
\text { його розумінні }\end{array}$ & $\begin{array}{l}\text { Цей етап еволюції аудиту тривав із } 1862 \text { до } 1905 \text { рр. Цей період відрізнявся висо- } \\
\text { ким зростанням економіки. Дуже великі за своїми розмірами угоди неминуче при- } \\
\text { звели до заснування корпорацій. Також цей період позначений появою консолідо- } \\
\text { ваного балансу (1904р.) }\end{array}$ \\
\hline
\end{tabular}


Закінчення таблиці 2

\begin{tabular}{|c|c|c|}
\hline Етап & Назва & Характеристика \\
\hline $\begin{array}{l}\text { Четвер- } \\
\text { тий етап }\end{array}$ & $\begin{array}{c}\text { Зміна } \\
\text { завдання } \\
\text { аудиту } \\
\end{array}$ & $\begin{array}{l}\text { Цей етап еволюції аудиту тривав із } 1905 \text { до } 1940 \text { рр. Характерними рисами аудиту } \\
\text { в цей період було те, що на аудит впливає Нью-Йоркська фондова біржа й урядові } \\
\text { організації; не було єдиної думки щодо цілей аудиту }\end{array}$ \\
\hline $\begin{array}{c}\text { П'ятий } \\
\text { етап }\end{array}$ & $\begin{array}{c}\text { Поява } \\
\text { аудиторського } \\
\text { ризику та } \\
\text { супутніх } \\
\text { аудиту послуг }\end{array}$ & $\begin{array}{l}\text { Цей етап еволюції аудиту пов’язаний з ускладненням бухгалтерського обліку } \\
\text { і збільшенням обсягу інформації, що підлягає перевірці в певні терміни. Це } \\
\text { неминуче призвело до необхідності застосування вибіркових перевірок, що стало } \\
\text { підставою для вимушеного допущення ризику аудиторської помилки. Методика } \\
\text { вибіркової перевірки встановлювалася з огляду на різні фактори, одним з яких був } \\
\text { професійний досвід аудитора }\end{array}$ \\
\hline
\end{tabular}

Періодизація автора охоплює не лише розвиток аудиту в сучасному етапі, але й загалом розвиток фінансового контрою в тій чи іншій країні. Автор не надає конкретних рис аудиту ні 3 погляду методології та завдань, ні з погляду функціонування суб’єктів аудиту.

Досить цікавими є пропозиції щодо періодизації розвитку аудиту, представлені в праці М.А. Азарської. Так, авторка визначає періодизацію розвитку аудиту в сучасному його розумінні як незалежного фінансового контролю. У контексті цього вона пропонує за кожним етапом виділяти цілі аудиту та основні методи. Це дозволяє оцінити еволюцію методології аудиту. Пропозиції авторки представлено в табл. 3 .

Таблиця 3

Еволюція цілей та методів аудиту [2, с. 12]

\begin{tabular}{|c|c|c|}
\hline Періодизація & Цілі аудиту & Методи \\
\hline $\begin{array}{l}\text { Перший період - передісторія } \\
\text { (до } 1850 \text { р.) }\end{array}$ & $\begin{array}{l}\text { Виявлення ефективності роботи, } \\
\text { запобігання зловживанням }\end{array}$ & $\begin{array}{l}\text { Детальна перевірка фактів господар- } \\
\text { ського життя }\end{array}$ \\
\hline $\begin{array}{l}\text { Другий період -виникнення } \\
\text { аудиту (1850-1905 рр.) }\end{array}$ & Виявлення зловживань & $\begin{array}{l}\text { Перевірка по суті (включаючи тесту- } \\
\text { вання окремих елементів) }\end{array}$ \\
\hline $\begin{array}{l}\text { Третій період - формування } \\
\text { професії (1905-1933рр.) }\end{array}$ & $\begin{array}{l}\text { Виявлення правильності відобра- } \\
\text { ження фінансового стану клієнта }\end{array}$ & Перевірка на відповідність і по суті \\
\hline $\begin{array}{l}\text { Четвертий період - станов- } \\
\text { лення професії (1933-1940 рр.) }\end{array}$ & $\begin{array}{l}\text { Виявлення правильності відобра- } \\
\text { ження фінансового стану; вияв- } \\
\text { лення помилки }\end{array}$ & $\begin{array}{l}\text { Тестування системи бухгалтерського } \\
\text { обліку і внутрішнього контролю }\end{array}$ \\
\hline \multirow[t]{2}{*}{$\begin{array}{l}\text { П'ятий період - сучасний стан } \\
\text { (1940 р. по теперішній час) }\end{array}$} & $\begin{array}{l}\text { Виявлення ефективності внутріш- } \\
\text { нього контролю }\end{array}$ & Стандартизація процесів перевірки \\
\hline & \multicolumn{2}{|c|}{$\begin{array}{l}\text { Цілі аудиту на консалтинговій основі пов'язані з оцінкою ризику перекру- } \\
\text { чень фінансової звітності, виявленням внутрішньовиробничих резервів. } \\
\text { Характеризується переходом від аудиту фінансової звітності до аудиту } \\
\text { бізнесу. Відмінні риси - використання ризик-орієнтованого підходу і } \\
\text { надання аудиторами широкого спектра супутніх аудиту та інших послуг, } \\
\text { пов’язаних з аудиторською діяльністю* }\end{array}$} \\
\hline
\end{tabular}

Визначені пропозиції свідчать про багатоаспектну періодизацію розвитку аудиту. У нашому дослідженні ми не ставимо за мету розробити періодизацію розвитку аудиту, ми лише намагаємося оцінити його властивості на кожному етапі суспільного розвитку з позиції суб'єктів аудиторської діяльності як суб'єктів ведення бізнесу.

Побудуємо дослідження історичних аспектів аудиту як господарської діяльності в такому порядку: витоки аудиту як інституту фінансового контролю; формування та еволюція аудиту в Україні (в складі Російської імперії та Радянського Союзу); поява аудиту та розвиток аудиту в сучасному його розумінні; сучасні тенденцій аудиту в країнах світу.

Витоки аудиту як виду фінансового контролю сягають стародавніх часів. Перші прояви контрольної діяльності можна прослідкувати в країнах стародавнього світу - Індії, Сгипті, Вавилоні, Китаї. «У Стародавньому Сході існували зачатки контролю за діяльністю бухгалтерів. Стародавні єгиптяни, китайці і шумери стежили за діяльністю чиновників. Історія аудиту як економічного явища йде в глибину століть. Елементи контролю застосовувалися в Стародавньому Вавилоні, де приблизно 5000 років тому використовувалися глиняні дощечки, які являли собою підтверджені аудитором звіти. За часів Середнього царства Нілу представник фараона спостерігав за зберіганням зерна. Аудит в ті часи полягав у спостереженні, підрахунку і повторному огляді звітів». Особливості аудиту в Індії визначаються 
положеннями «Артхашастри, або науки політики», що є наукою про державний устрій, яка передбачає окремі положення щодо ведення рахунків в обліковому відомстві.

Я.В. Соколов вказує: «Елементи ревізійної діяльності застосовувалися у Вавилоні і Давньому Єгипті при оцінці правильності збору податків, а в середні віки - у сфері торгівлі. У Стародавньому світі мала місце публічно-правова звітність. Так, за свідченнями Геродота, на піраміді Хеопса було вирізано, скільки часнику, редиски, цибулі та інших продуктів було видано людям, зайнятим на будівництві піраміди, загальна вартість якої становить 1500 талантів. До нас дійшов звіт, вирізаний на стіні Парфенона, згідно з яким вартість будівництва становила 469 талантів» [18, с. 31]. «Деякі вчені вважають, що в Китаї вперше була створена аудиторська система в 700 р. до н. е. за часів династії Чжоу (1122-256 рр. до н. е..) Державна система мала стрункий бюджет, проводився аудит всіх урядових компаній. Однак стародавні аудитори були, як правило, державними службовцями, і про незалежність аудиту не могло бути й мови» [1]. Більшою мірою потреба в контролі була пов'язана із функціонуванням державної казни та сплатою податків. Так, І.Д. Голяш вважає, що «історичні факти рабовласницького світу слугують підгрунтям для розуміння аудиту як однієї з процедур господарського контролю, але не як самостійної професії» [8].

У добу античності аудит як інститут фінансового контролю мав особливості в різних країнах.

Греція. «У Греції в V ст. до н. е. існувала система контролю доходів і витрат із боку Народних Зборів, а фінансова система включала урядових аудиторів, які перевіряли документи всіх посадових осіб по закінченні їх повноважень < .. > Відомі філософи Греції приділяли належну увагу обліку і контролю. Так, Аристотель у «Політиці» чітко розмежував облікові і контрольні функції, причому розглядав ревізію як частину контролю» $[11$, с. 62-63].

Рим. «У Римській імперії з VII ст. до н. е. контрольні функції здійснювали куратори, прокуратори, квестори, які контролювали державних бухгалтерів на місцях» [16, с. 50]. «У Стародавньому Римі метою обліку був в основному контроль господарської діяльності, сплати податків. Було створено складний апарат ревізорів і контролерів, і все ж факти шахрайства, ухилення від сплати податків були не поодинокі. Облік мав запобігати збиткам, які виникали внаслідок шахрайства або невміння вести господарство. У період середньовіччя разом із розвитком суспільно-економічних відносин удосконалюються облік і контроль господарської діяльності, з'являються спеціальні трактати про контроль обліку і звітності, який нині здійснює аудит. Контроль стає головним знаряддям збереження приватної власності, тому до XX ст. основна функція обліку була суто контрольною» [14].

Таким чином, стародавній світ $€$ витоком аудиту з позиції основної мети - контролю за господарською діяльністю (в основному державної казни), а також становленням професії аудиту. «Епоха Середньовіччя характеризується повільним розвитком аудиту. Після розпаду Римської імперії у зв'язку з розширенням зовнішньої торгівлі аудит продовжував розвиватися у Венеції, Флоренції, Генуї. Головною метою аудиторів того часу був контроль правильності ведення обліку. В Свропі аудит на той період ще не здобув широкого застосування, тільки у Великобританії та Франції продовжувала своє формування система аудиту, основною метою якої був контроль сплати податків, формування і витрачання державних коштів» [8].

Проте аудит у сучасному розумінні виник набагато пізніше у Великобританії. Слід зазначити, що в сучасному розумінні аудит виник у Великобританії, коли була створена нормативно-правова база i повною мірою закріплений принцип незалежності як один 3 основоположних принципів аудиту. У 1862 р. був прийнятий закон про обов'язковий аудит, і аудит був визнаний окремою галуззю економічної науки. Однак до 1862 р. є згадки про аудит у вигляді практичної діяльності, про його окремі прийоми, використовувані і в наші дні [10]. Батьківщина сучасного аудиту - Англія. Ще в IX ст. із загального поняття «бухгалтер» виділяється суміжне поняття «аудитор». За першим у його повсякденній діяльності зберігаються функції особи, що організовує і веде рахунки, а на другого покладаються самостійні незалежні функції контролера, що перевіряє рахунки [21].

Проте перша згадка про аудит у Великобританії була маже за сім століть раніше, а саме у 1130 р., що було встановлено на основі вивчення архівів казначейства Англії і Шотландії. Зарубіжні вчені Ф.Л. Дефлиз, Г.Р. Дженик, В.М. Рейлли, М.Б. Хирш вказують: «Лондонське Сіті піддавалося аудиту в 1200-і рр. На початку XIV століття в числі виборних посадових осіб значилися і аудитори. В архівах того періоду міститься безліч документів, які свідчать про широке визнання значення аудиту і регулярне здійснення аудиту звітів муніципалітетів, приватних землеволодінь і ремісничих гільдій» [4, с. 23].

Своєю чергою вітчизняні вчені І.Д. Голяш та Л.А. Будник зазначають: «Поновлення інтересу до аудиту характеризується появою інформації про нього у Великобританії на початку XII ст. Але тільки в XIII ст. аудит набув державного визнання, що підтверджується виданням у 1285 р. першого у світі законодавчого 
акта, який регламентував аудиторську діяльність. Продовженням історії стало підписання в 1324 р. указу про призначення трьох державних аудиторів, що свідчить про значне пожвавлення інтересу до аудиту. 3 цього часу почалося становлення незалежного аудиту в сучасному його розумінні» [8].

Подібні історичні положення містяться в праці Я.В. Соколова: «Першим законодавчим актом, що регулює діяльність аудиторів, був закон, складений в 1285 р. королем Англії Едуардом І. Відповідно до цього закону аудиторами від імені держави були не тільки особи з числа довірених слуг сеньйорів, а й деякі категорії цивільних службовців, і всім надавалися певні привілеї. Таким чином, з'являються перші зачатки застосування принципу незалежності в аудиті. Королем Едуардом II 24 березня 1324 р. був підписаний указ про призначення трьох державних аудиторів, в обов'язки яких входила перевірка рахунків. Їм ставилося в обов'язок брати всі рахунки, які були введені і які будуть введені в провінціях: Оксфорді, Беркенхенде, Саутхемптоне, Уельсі, Соммерсетшіре і Дорсеті, «робити і позначати все, що аудитори з рахунками робити мають» [19].

Проте все ж таки прототип сучасного регульованого незалежного аудиту зародився у 1844 р. «в Англії введено обов'язковий аудит відповідно до низки прийнятих законів про компанії, які зобов'язували правління акціонерних компаній запрошувати (не рідше одного разу на рік) фахівця для перевірки бухгалтерських рахунків і обов'язкового звіту перед акціонерами» [10]. «Найважливішою віхою в історії становлення аудиторської діяльності як обов'язкової форми контролю послужило видання в 1862 р. у Великобританії закону про британські компанії (The Companies Act 1862), в якому було запропоновано в обов'язковому порядку перевіряти рахунки і звіти компаній аудиторами не рідше одного разу на рік. Крім того, наприкінці XIX століття в багатьох європейських державах формуються професійні спільноти (інститути) бухгалтерів-аудиторів, а також приймаються законодавчі акти, що передбачають обов'язкову щорічну незалежну перевірку фінансових звітів компанії та надання результатів таких перевірок акціонерам» [20].

Британська практика розвитку аудиту показала певний відбиток на його формування в Німеччині та США, зокрема: у США аудиторська діяльність розвивалася під впливом британської практики аудиту, «коли англійські залізничники, страхові компанії та інші інвестори попрямували до Північної Америки, разом із ними поїхали і незалежні аудитори для захисту інтересів великих англійських кредиторів» [5]. Така практика тривала аж до ХХ століття. «У 1896 р. в штаті Нью-Йорк законодавчо було закріплено, що посаду аудитора міг обіймати дипломований бухгалтер, який успішно склав іспит за фахом у НьюЙоркському університеті й отримав спеціальну ліцензію на право займатися аудиторською діяльністю» [7]; в Німеччині на основі досвіду розвитку англійського аудиту у 1884 р. було створено інститут бухгалтерів-ревізорів. Проте ще в 1870 р. було «прийняте доповнення до закону про акціонерні товариства, що зобов'язало наглядові ради цих товариств здійснювати перевірку балансу, звіту про поширення прибутку і доповідати про результати перевірки на загальних зборах акціонерів без уточнення, ким саме має проводитися така перевірка - власними (внутрішніми ) ревізорами або ж запрошеними зі сторони». Варто зазначити, що основним поштовхом до формування концепції незалежного аудиту в Німеччині була Грюндерська лихоманка, що стала передумовою краху акціонерних товариств.

Історичні аспекти розвитку в Україні здебільшого пов'язані з особливостями системи фінансового контролю в Російській імперій, а в подальшому - в Радянському Союзі.

Аудит був введений Петром I, але по суті своїй це був державний фінансовий контроль вузької спрямованості у сфері майнових відносин в армії. Як незалежна форма контролю аудит у Російській імперії так і не сформувався. Для цілей розвитку професії робилися спроби проведення іспитів у 1888, 1907-1912 pр. Однак у разі потреби проведення аудиторської перевірки в Російській імперії запрошувалися закордонні аудитори. Нормативного регулювання аудиторської діяльності з боку державних органів не проводилося, а використовувалися положення, що регламентують аудиторську діяльність, прийняті в інших країнах. Після жовтня 1917 р. потреба в аудиті як одній із форм комерційної діяльності зникає, бо була проведена націоналізація господарюючих суб'єктів і фінансовий контроль повністю стає державним. НЕП відродив аудиторський контроль на нетривалий час, що було зумовлено появою комерційних організацій [22].

«Надалі було зроблено ще кілька спроб створення інституту аудиту в Росії, так, у 1891 р. був проведений І з'їзд рахівників, на якому оголосили про відкриття Товариства рахівників. Його першочерговим завданням стало утворення групи «присяжних рахівників», яким доручалися ревізії різних рахівництва, експертиза та організація правильної бухгалтерії на приватних і громадських підприємствах. Але це починання не знайшло розуміння і підтримки в професійному середовищі. Основною перешкодою стало неприйняття вимоги конфіденційності (аудитор не може повідомляти про виявлені порушення нікому, крім клієнта) і самої суті відносин між організацією і аудитором (аудитор не тільки перевіряє 
фінансові документи, а й описує в акті виявлені недоліки і порушення). 3 цієї та низки інших причин проєкт про заснування Інституту бухгалтерів і присяжних рахівників так і не був затверджений Державною Радою» [18]. За своїм характером посада аудитора відрізнялася від аналогічної посади в Західній Європі, бо в Росії аудиторами називалися юристи, які поєднують у своїй діяльності функції діловода, секретаря і прокурора [15].

Чергова спроба розвитку аудиторської діяльності була зроблена вже в Радянському Союзі, в роки НЕПу, коли в 1925 р. при Народному комісаріаті робітничо-селянської інспекції СРСР створено Інститут державних бухгалтерів експертів (ІГБЕ). Інститут створювався з метою сприяння та правильної постановки рахівництва і звітності в державних, концесійних, змішаних, кооперативних, громадських і приватних підприємствах і державних установах. Таким чином, завдання цієї установи визначалися як сприяння правильній постановці обліку в країні і проведення експертиз із питань рахівництва і звітності на вимогу державних органів. Діяльність інституту мала замкнутий характер, оскільки весь накопичений у процесі роботи матеріал представлявся у вигляді висновків і доповідей у Центральні бюро ІГБЕ, а потім відправлявся в сховища. Відповідно, всі виявлені недоліки та досягнення в галузі постановки обліку і звітності не публікувалися [17]. Надалі в Радянському Союзі аудит як незалежний вид фінансового контролю не розвивався. Усі контрольні функції були покладені на державні контролюючі органи. Лише в період перебудови та отримання незалежності республіками Радянського Союзу, що спонукало до ринкових відносин, починає зароджуватися аудит у сучасному його розумінні за прикладами передового досвіду країн Заходу.

П.П. Баранов, характеризуючи витоки сучасних тенденцій розвитку аудиту як інструменту незалежного фінансового контролю та як виду господарської діяльності в консалтинговій сфері, вказує на те, що «поява і інтенсивна експансія аудиторської діяльності в Західній Європі в XIX ст. стали наслідком так званої четвертої управлінської революції, в рамках якої відбулося відділення менеджменту від власності та формування спільноти професійних управлінців. Віддалення власників бізнесу від власне бізнесу і процесів формування інформації, що характеризує ефективність останнього, породило об'єктивну суперечність інтересів власника і менеджера, зумовлену традиційним підходом до мотивації управлінців, пов'язується ефективність управлінської праці з ефективністю діяльності об'єкта управління. Експлуатація такої моделі мотивації, з одного боку, практично неминуча, але з іншого вона створює благодатний грунт для вуалювання і фальсифікації бухгалтерської фінансової звітності, аналізуючи яку власник робить висновки про фінансовий і майновий стан належної йому бізнес-одиниці, результати iï господарської діяльності та приймає в числі інших найважливіше для менеджера рішення - рішення про розмір і форму його винагороди. Подолання цього протиріччя було неможливим без появи у зв'язці «власник - менеджер» третього суб'єкта - незалежного аудитора, покликаного за допомогою спеціальних методів давати оцінку достовірності економічної інформації, наділяти менеджментом у форму бухгалтерської фінансової звітності та використовуваної власниками в процесі формування своєї лінії поведінки щодо власного бізнесу [7].

Твердження автора вказує на те, що аудит як вид бізнесу характеризується значною мінливістю щодо факторів зовнішнього середовища. Вважаємо, що сучасний стан аудиту як вид незалежного фінансового контролю та як вид господарської діяльності визначається зовнішнім середовищем із таких позицій:

- по-перше, специфіки соціально-економічних відносин із позиції об'єкта аудиту як інструменту незалежного фінансового контролю;

- по-друге, специфіки розвитку управлінської науки 3 позиції появи аудиту як інструменту взаємозв'язку між управлінськими ланками;

- по-третє, розвитку аудиту як консалтингу з позиції аудиторської діяльності як виду бізнесу.

Сучасний стан аудит як виду незалежного фінансового контролю та як виду господарської діяльності в різних країнах світу характеризується певним станом соціально-економічних відносин. Вивчаючи сучасний стан розвитку аудиту та діяльності аудиторських фірм у країнах світу, насамперед варто наголосити на тенденції до уніфікації процесу регулювання аудиту та аудиторської діяльності. Це в першу чергу стосується країн Європейського Союзу. «Сучасний міжнародний аудит характеризується тим, що майже у всіх розвинених країнах світу існує громадський Інститут професійного аудиту, який має свою правову та організаційну інфраструктуру. Але існують і відмінності в державному контролі аудиторської діяльності. Аудиторські фірми Великобританії характеризуються великою самостійністю з питань підготовки, присвоєння кваліфікації, контролю якості виконання аудиторами професійних обов'язків. Аудиторська діяльність у країнах континентальної Європи суворо регулюється державою. Аудит у країнах Європейського Союзу регламентується нормативно-правовими актами, прийнятими в урядових структурах. У цих країнах поряд з аудиторами, що займаються перевіркою бухгалтерських звітів і балансів, виділяють специфічну категорію аудиторів-консультантів із питань оподаткування» [12, с. 341]. 
«Нині значний вплив на правове регулювання аудиту справляють процеси, пов'язані з економічною інтеграцією країн $€ C$, які передбачають уніфікацію практики бухгалтерського обліку та аудиту. Зокрема, регулюванню аудиторської діяльності присвячені Директива 2014/56/ЄС Європейського парламенту та Ради від 16 квітня 2014 року про внесення змін до Директиви 2006/43/ЄК з обов'язкового аудиту річної звітності та консолідованої звітності, Регламент ЄС № 537/2014 Європейського Парламенту та Ради від 16 квітня 2014 року про особливі вимоги до обов'язковому аудиту суб' єктів суспільного інтересу і скасування Рішення 2005/909/СК Свропейської Комісії та Директиви 89/48/EЕC і 92/51/EЕС про взаємне визнання професійної кваліфікації, що діють у всіх державах-членах $\mathrm{CC}$, а також у Норвегії, Ісландії та Ліхтенштейні» [7, с. 126].

На основі вивчення наукової, навчальної, довідкової літератури та нормативно-правових актів і аналітичних доповідей представимо особливості регулювання аудиторської діяльності в країнах Західної Європи, які за економічним розвитком, політичною та правовому системами та участю в міжнародних об'єднаннях знаходяться в різних групах. Особливості інституційного забезпечення аудиторської діяльності в країнах Західної Європи представлено в табл. 4. Під інституційним забезпеченням ми розуміємо сукупність державних, професійних та суспільних інституцій, основними функціями яких $є$ регулювання аудиту та аудиторська діяльність.

Таблиця 4

Інституційне забезпечення регулювання аудиторської діяльності в країнах Західної Свропи

\begin{tabular}{|c|l|}
\hline Країна & \multicolumn{1}{|c|}{ Органи регулювання аудиторської діяльності } \\
\hline Франція & $\begin{array}{l}\text { Палата експертів-бухгалтерів } \\
\text { Національна компанія комісарів рахунків }\end{array}$ \\
\hline Італія & Міністерство Юстиції \\
\hline Болгарія & Інститут дипломованих експертів-бухгалтерів \\
\hline Німеччина & $\begin{array}{l}\text { Аудиторська палата } \\
\text { Інститут аудиторів } \\
\text { Федеральне міністерство економіки }\end{array}$ \\
\hline Польща & $\begin{array}{l}\text { Загальнодержавна Рада Аудиторів } \\
\text { Надзвичайний Загальнодержавний 3’їд Професійних Аудиторів } \\
\text { Загальнодержавна Кімната Аудиторів }\end{array}$ \\
\hline Білорусь & $\begin{array}{l}\text { Спілка аудиторів } \\
\text { Аудиторська палата }\end{array}$ \\
\hline Литва & $\begin{array}{l}\text { Литовська Асоціація бухгалтерів та аудиторів (ЛАБА) } \\
\text { Аудиторська Палата Литви }\end{array}$ \\
\hline Молдова & $\begin{array}{l}\text { Рада з нагляду за аудиторською діяльністю при Міністерстві фінансів } \\
\text { Професійні неурядові організації }\end{array}$ \\
\hline Бельгія & Бельгійський інститут зареєстрованих аудиторів \\
\hline Греція & $\begin{array}{l}\text { Інститут сертифікованих аудиторів Греції } \\
\text { Рада з нагляду за бухгалтерським обліком і аудитом }\end{array}$ \\
\hline Ірландія & $\begin{array}{l}\text { Інститут присяжних бухгалтерів Ірландії } \\
\text { Інститут присяжних бухгалтерів Англії та Уельсу } \\
\text { Ірландський аудиторський та бухгалтерський наглядовий орган }\end{array}$ \\
\hline & \\
\hline
\end{tabular}

У таблиці 5 представлено специфіку системи регламентації аудиту в таких країнах Західної Європи, як Бельгія, Греція та Ірландія.

Таблиця 5

Сучасні системи регулювання аудиторської діяльності в кранах Західної Свропи

\begin{tabular}{|c|c|c|}
\hline Бельгія & Греція & Ірландія \\
\hline \multicolumn{3}{|c|}{ Регулюючі органи } \\
\hline $\begin{array}{l}\text { Бельгійський інститут зареєстрова- } \\
\text { них аудиторів }\end{array}$ & $\begin{array}{l}\text { Інститут сертифікованих аудиторів } \\
\text { Греції } \\
\text { Рада з нагляду за бухгалтерським } \\
\text { обліком і аудитом }\end{array}$ & $\begin{array}{l}\text { Інститут присяжних бухгалтерів } \\
\text { Ірландії; } \\
\text { Інститут присяжних бухгалтерів } \\
\text { Англії і Уельсу; } \\
\text { Ірландський аудиторський та бух- } \\
\text { галтерський наглядовий орган }\end{array}$ \\
\hline
\end{tabular}


Закінчення таблиці 5

\begin{tabular}{|c|c|c|}
\hline Бельгія & Греція & Ірландія \\
\hline \multicolumn{3}{|c|}{ Мета регулюючих органів } \\
\hline $\begin{array}{l}\text { IBR-IRE встановлює стандарти } \\
\text { аудиту, Верховна Рада з економіч- } \\
\text { них професій стверджує їх. IBR-IRE } \\
\text { здійснює контроль якості аудитор- } \\
\text { ської діяльності }\end{array}$ & $\begin{array}{l}\text { Моніторинг діяльності аудиторів, } \\
\text { зареєстрованих у SOE, контроль } \\
\text { дотримання аудиторами законодав- } \\
\text { ства, професійних і етичних норм і } \\
\text { стандартів }\end{array}$ & $\begin{array}{l}\text { Контроль роботи аудиторів, внесе- } \\
\text { них до реєстру, процесу реєстрації } \\
\text { зовнішніх аудиторів, моніторинг } \\
\text { дотримання ними законодавства в } \\
\text { галузі аудиту }\end{array}$ \\
\hline \multicolumn{3}{|c|}{ Застосування обов'язкового аудиту } \\
\hline $\begin{array}{l}\text { Компанії, показники яких переви- } \\
\text { щують два з трьох критеріїв два } \\
\text { роки поспіль: річний оборот - 7,3 } \\
\text { млн євро; активи - 3,65 млн євро; } \\
\text { чисельність співробітників - } 50 \text { чол. } \\
\text { Компанії з більш ніж } 100 \text { співробіт- } \\
\text { никами. Дочірні компанії. Компанії, } \\
\text { статут яких вимагає обов’язкового } \\
\text { аудиту }\end{array}$ & $\begin{array}{l}\text { Організації, показники яких пере- } \\
\text { вищують два } 3 \text { трьох встановлених } \\
\text { обмежень: загальна сума активів - } \\
4 \text { млн євро, чистий оборот - } \\
8 \text { млн євро, середня чисельність } \\
\text { працівників - } 50 \text { чол. }\end{array}$ & $\begin{array}{l}\text { Публічні компанії. Компанії, } \\
\text { що перевищують одну з умов } \\
\text { (для поточного } \\
\text { і попереднього фінансового року): } \\
\text { оборот - 8,8 млн євро, активи - } \\
4,4 \text { млн євро наприкінці фінансо- } \\
\text { вого року, середнє число працівни- } \\
\text { ків - 50. Компанії, до яких не засто- } \\
\text { совується Сотрапіеs (поправка) } \\
\text { 1986. Материнські або дочірні } \\
\text { компанії }\end{array}$ \\
\hline \multicolumn{3}{|l|}{ Вимоги до аудиторів } \\
\hline $\begin{array}{l}\text { Відповідати вимогам освіти і сер- } \\
\text { тифікації. Член IBR-IRE має право } \\
\text { надавати свої послуги (ліцензія). } \\
\text { Аудитори призначаються акціо- } \\
\text { нерами за пропозицією комітету з } \\
\text { аудиту, якщо такі є }\end{array}$ & $\begin{array}{l}\text { Включені до реєстру аудиторів, } \\
\text { дотримуються законодавства, про- } \\
\text { фесійні та етичні норми. Норма- } \\
\text { тивний аудитор, аудиторська фірма } \\
\text { призначається загальними зборами } \\
\text { акціонерів суб’єкта, що перевіря- } \\
\text { ється. }\end{array}$ & $\begin{array}{l}\text { Член професійно визнаної профе- } \\
\text { сійної організації. Реєстрація ауди- } \\
\text { торської фірми в ICAEW дає змогк } \\
\text { працювати як у Великобританії, так } \\
\text { і в Ірландії }\end{array}$ \\
\hline \multicolumn{3}{|l|}{ Ротація аудиторів } \\
\hline $\begin{array}{l}\text { Аудитори призначаються на три } \\
\text { роки поспіль, максимальний період } \\
\text { - дев'ять років. Період охоло- } \\
\text { дження - два роки }\end{array}$ & $\begin{array}{l}\text { Аудитор може запропонувати свої } \\
\text { послуги на період пошукових } \\
\text { робіт, що не перевищує п’ять років } \\
\text { поспіль, і відновити свої обов’язки } \\
\text { після закінчення двох років поспіль }\end{array}$ & $\begin{array}{l}\text { Нині вимоги з ротації аудиторів не } \\
\text { визначені }\end{array}$ \\
\hline \multicolumn{3}{|l|}{ Вимоги до аудиторського звіту } \\
\hline $\begin{array}{l}\text { Узгоджується з внутрішнім аудито- } \\
\text { ром і керівництвом фірми. Звісно ж, } \\
\text { власником і Спостережною комі- } \\
\text { сією IBR-IRE, члени якого мають } \\
\text { право вето на призначення аудитора }\end{array}$ & $\begin{array}{l}\text { Якщо обов’язковий аудит прове- } \\
\text { дено кількома офіційними аудито- } \\
\text { рами або аудиторськими фірмами, } \\
\text { в разі їх згоди з результатами } \\
\text { обов'язкового аудиту надаються } \\
\text { спільна доповідь і думка. У разі } \\
\text { виникнення розбіжностей кожен } \\
\text { аудитор або аудиторська фірма має } \\
\text { представити свою думку в окре- } \\
\text { мому розділі аудиторського звіту та } \\
\text { обгрунтувати свої заперечення }\end{array}$ & $\begin{array}{l}\text { Додатково у звіті розкривається } \\
\text { думка аудитора з питань: чи } \\
\text { отримав аудитор всі дані і пояс- } \\
\text { нення, необхідні для перевірки; чи } \\
\text { ведуться в компанії всі необхідні } \\
\text { бухгалтерські документи; отримані } \\
\text { дані від підрозділів, які аудитор } \\
\text { особисто не відвідав; чи відповіда- } \\
\text { ють баланс і звіт про прибутки і } \\
\text { збитки обліковим даним }\end{array}$ \\
\hline
\end{tabular}

Джерело: розроблено на основі [6]

Подібні та водночас різні тенденції спостерігаються в інших країнах світу. Так, Великобританія та США є своєрідними «законодавцями моди» у сфері аудиту, що пов'язано з функціонуванням на їхній території найбільших ринків цінних паперів (Лондонська Фондова біржа та Нью-Йоркська фондова біржа). Нами розглянуті праці вчених, які характеризують розвиток аудиту як виду професійної та господарської діяльності в країнах світу, зокрема Азії:

- Казахстан. «Аудиторські послуги в Казахстані розвиваються швидкими темпами, хоча і є проблеми в їх застосуванні. На вирішення проблем впливає збільшення конкурентів на ринку аудиторських послуг, тобто кількість аудиторів збільшується, і тому потрібно мати високу обізнаність у цій галузі, щоб мати постійних клієнтів, які були б задоволені роботою аудитора. Нині в Казахстані працюють лише 500 аудиторів у складі 129 аудиторських організацій на приблизно 8 тис. підприємств громадського інтересу, налічується близько 5 тис. сертифікованих аудиторів і близько 3 тис. суб'єктів аудиторської діяльності, які внесені до реєстру аудиторських фірм та аудиторів. При цьому в реєстрі 
налічується близько 0,5 тис. компаній і 2,5 тис. фізичних осіб аудиторів-підприємців. Сукупний обсяг ринку аудиторських послуг оцінюється на рівні 80 млн дол. на рік або близько 4,1 тис. дол. у розрахунку на одного сертифікованого аудитора. Також проблемою є недостатня кількість кваліфікованих аудиторських кадрів, яка тягне за собою неосвоєння ринку аудиторських послуг» [21];

- Республіка Корея (неофіційна назва - Південна Корея). «Зі збільшенням обсягів міжнародної торгівлі, залученням міжнародних інвестицій у Кореї зростає потреба в ефективних системах зовнішнього аудиту. У 1980 р. був прийнятий Закон про зовнішній аудит, який зобов’ язував корпорації з певними активами проходити обов'язковий аудит за допомогою зовнішніх аудиторів. Найважливішими документами у сфері регулювання діяльності зовнішнього аудитора $є$ прийняті в Республіці Корея Міжнародні стандарти аудиту, скориговані відповідно до корейської специфіки, названі КСА - Корейські стандарти аудиту. Між міжнародними та корейськими стандартами аудиту є низка відмінностей. Однак нині ознайомитися 3 корейськими стандартами аудиту можна тільки корейською або англійською мовою» [17].

Висновки. Аналіз сучасного етапу розвитку аудиторської діяльності у світі вказує на відсутність єдиних світових підходів до регулювання аудиту. Кожна країна розробляє власні підходи до інструкційного забезпечення регулювання аудиту та встановлює специфічні вимоги до діяльності аудиторської фірми. Варто зауважити, що основною характеристикою сучасного аудиту є встановлення вимог власне до кадрового потенціалу аудиторської фірми.

\section{Література:}

1. Абрютина М.С., Грачева А.В. Анализ финансово-экономической деятельности. Москва : ДИС, 1998. 256 с.

2. Азарская М.А. Методология и развитие методического обеспечения его качества : монография. Йошкар-Ола : ООО «Стринг», 2009.

3. Андреев В.Д. Практический аудит. Москва : Экономика, 1994.

4. Аудит Монтгомери / Ф.Л. Дефлиз, Г.Р. Дженик, В.М. Рейлли, М.Б. Хирш; пер. с англ.; под ред. Я.В. Соколова. Москва : Аудит; ЮНИТИ, 1997.

5. Бикова В.Г. Фінансово-економічний потенціал підприємств загальнодержавного значення - оцінка і управління. Фінанси Украӥни. 2005. № 6. С. 56-61.

6. Волошина Е.И. Особенности аудиторской деятельности в странах Западной Европы. Научныій вестник: финансы, банки, инвестиции. 2017. № 3. С. 124-130.

7. Воронина Л.И. Основы современного бухгалтерского учета и аудита : учеб. пособие: в 2 ч. Основы аудита. Москва, 1999. Ч. 2. Основы аудита. 1997. 252 с.

8. Голяш І.Д., Будник Л.А. Тенденції розвитку аудиту: ретроспективний погляд та проекція на майбутнє. Науковий вісник Херсонського державного університету. Сер. : Економічні науки. 2016. Вип. 17(1). С. 130-133.

9. Гуцаленко Л.В., Марченко C.O.Реалії аудиту у вітчизняній та зарубіжній практиці. URL: https://chmnu.edu.ua/ wp-content/uploads/2019/06/Ekonomika-i-suspilstvo-6-2016.pdf\#page=349

10. Кизилов А.Н., Богатая И.Н. Эволюция аудита как науки и практической деятельности. Международный бухгалтерский учет. 2012. № 34. URL: https://cyberleninka.ru/article/n/evolyutsiya-audita-kak-nauki-i-prakticheskoy-deyatelnosti-1

11. Кужельный Н.В. Бухгалтерский учет и его контрольные функции: Практическое руководство. Москва : Финансы и статистика, 1985. $143 \mathrm{c}$.

12. Кучеров А.В., Козичева Я.М. Особенности аудита за рубежом. Молодой ученый. 2013. № 5. С. 339-343.

13. Лавренова Е.С. Особенности развития аудита в историческом аспекте с точки зрения американской экономики. URL: https://cyberleninka.ru/article/n/osobennosti-razvitiya-audita-v-istoricheskom-aspekte-s-tochki-zreniya-amerikanskoyekonomiki/viewer

14. Лебедєв О.П. Історичні аспекти зародження та розвитку контролю фінансової сфери країни. URL: http:// adminpravo.com.ua/index.php/2010-04-13-14-05-13/61-2010-07-08-14- 15-02/701-11-.html

15. Макоед И.А., Пупко Г.М. Аудит: в 2 ч. Ч. 1 . Минск : НИУ, 2009. 227 с.

16. Мельничук Б.В. Еволюція сутності аудиту. Економіка АПК. 2011. № 12. С. $49-57$.

17. Пименов Д.М. Анализ и обобщение исторических аспектов развития аудита в России. Вестник Московского университета МВД России. 2013. № 9. С. 292-302.

18. Соколов Я.В. Очерки по истории бухгалтерского учета. Москва : Финансы и статистика, 1991.

19. Соколов Я.В., Бычкова С.М. Роль теории аудита в процессе подготовки кадров. Аудиторские ведомости. 1998. № 2.

20. Степанова Я.В. Задачи аудита: эволюция и перспективы. ТДР. 2012. № 6-1. URL: https://cyberleninka.ru/article/n/ zadachi-audita-evolyutsiya-i-perspektivy.

21. Султанова К.Т. Тенденции развития аудиторской деятельности в Казахстане. Педагогическая наука и практика. 2019. № 3 (25). URL: https://cyberleninka.ru/article/n/tendentsii-razvitiya-auditorskoy-deyatelnosti-v-kazahstane.

22. Торопова И.С. Аудит в Российской Федерации: история развития и современное состояние. Научный вестник: финансы, банки, инвестииии.2017. № 4 (41). С. 153-157.

23. Усанова Н.Г. История развития аудита. URL: http://www.buk.irk.ru/library/sbornik_03/6.shtml. 